\title{
To What Degree Can the Specifics of Occurrence of Glacial Relic Betula humilis Schrank Be an Indicator of Habitat Conditions of Moderate Climate Peatlands?
}

\author{
Artur Serafin ${ }^{1}$ (1) , Danuta Urban ${ }^{2}$, Urszula Bronowicka-Mielniczuk ${ }^{3, * \text { (1) }}$ \\ and Agnieszka Szczurowska 4 \\ 1 Department of Environmental Engineering and Geodesy, University of Life Sciences in Lublin, \\ Leszczyńskiego 58 str., 20-068 Lublin, Poland; artur.serafin@up.lublin.pl \\ 2 Institute of Soil Science, Engineering and Environmental Sciences, University of Life Sciences in Lublin, \\ Leszczyńskiego 7 str., 20-069 Lublin, Poland; danuta.urban@up.lublin.pl \\ 3 Department of Applied Mathematics and Computer Science, University of Life Sciences in Lublin, \\ Głęboka 28 str., 20-612 Lublin, Poland \\ 4 Department of Plant Physiology, University of Life Sciences in Lublin, Akademicka 15 str., \\ 20-950 Lublin, Poland; agnieszka.szczurowska@up.lublin.pl \\ * Correspondence: urszula.bronowicka@up.lublin.pl; Tel.: +48-81-5319626
}

Received: 13 July 2018; Accepted: 7 August 2018; Published: 10 August 2018

\begin{abstract}
Anthropogenic transformations of habitat conditions in moderate climate peatlands frequently cause a decrease in the number of sites of occurrence and the size of the population of many valuable plant species, including the boreal relic Betula humilis. The objective of this paper was an attempt to relate the specifics of the occurrence of the glacial relic Betula humilis in the peatlands of Central-Eastern Poland, which developed under moderate climate conditions, to the conditions of the natural environment identified through research into the physical and chemical parameters of the groundwater, as well as botanical research into its habitat. The study results confirm that shrub birch has a broad range of ecological tolerance to the majority of the studied factors and can therefore be an indicator of habitat transformation. Important environmental factors affecting its abundance are water relations and the contribution of calcium hydroxide and phosphorus fractions. A condition favouring the proper functioning of individuals of the studied species is TP values lower than other obtained values, in the following range: 0.08-0.32; $\mathrm{P}_{-\mathrm{PO}_{4}}: 0.1 ; \mathrm{TN}$ : 2.2-21.2; $\mathrm{N}-\mathrm{NH}_{4}$ : $0.1-0.46$; DOC: $24.6-55.9\left(\mathrm{mg} \cdot \mathrm{dm}^{-3}\right)$, as well as higher than average $\mathrm{pH}$ values, in the following range: 5.34-5.95; Ca: 5.67-28.1; Mg: 0.56-2.41 $\left(\mathrm{mg} \cdot \mathrm{dm}^{-3}\right)$ and EC: $72.1-142.3\left(\mu S \cdot \mathrm{cm}^{-1}\right)$.
\end{abstract}

Keywords: shrub birch; boreal relic; habitat; physical-chemical parameters; peatlands

\section{Introduction}

Specific peatland ecosystems develop only in the moderate climate zone of the Northern Hemisphere in climate conditions that determine considerable plant production, and that are unfavourable to the processes of decomposition of plant remains. The prevalence of production processes over the processes of destruction of organic matter in conditions of a humid moderate climate-with a prevalence of precipitation over evapotranspiration-provides for the accumulation of peat, which occurs through a modifying approach to the biocoenotic composition of phytocoenoses and in conditions of appropriate hydrological relations [1]. 
Peatland flora plays an important role in the development of species biodiversity, particularly in the central part of East Poland, where relatively large and typologically varied peatlands occur, subject to low human pressure, in moderate climate conditions with strong continentalism [2].

The particular habitat requirements related to the evolutional adjustment of the effect of the northern continental climate are observed here in the case of rare and protected Pleistocene boreal relics such as e.g., Betula humilis, Salix lapponum, or Salix myrtilloides [3-9]. In spite of numerous morphological, anatomical, physiological, and ecological adaptations permitting their survival in often extreme environmental conditions [3,10-12], the rate of environmental transformations related to the fluctuations of the moderate climate and progressing human pressure are occurring too fast for the species. Whereas fluctuations of climatic factors indirectly result from human activity, which narrows the range of ecological valency of many species, direct anthropogenic landscape transformations in the environment result in the fragmentation of many valuable natural habitats, changing the abiotic and biocoenotic environmental conditions [13,14].

This is additionally favoured by the frequent occurrence of such plants at isolated sites with limited accessibility to proper habitats. Due to this, they respond to environmental transformations by limiting the possibilities of effective reproduction and dispersion. The effect of environmental transformations can therefore be a decrease in the number of sites of occurrence of glacial relics, and a successive shrinking of their populations. Local populations of such species are therefore under actual threat of extinction and the further restriction of their range of occurrence $[5,8,9]$.

In such conditions, the specificity of the occurrence of boreal relics can reflect changes in their habitats, particularly in reference to hydrological conditions that are often modified anthropogenically [3,6-9].

On the other hand, relic plants are less resistant to dynamic habitat transformations, particularly those related to climate fluctuations and human pressure, as they are subject to full legal species protection in Poland, but often require active protection measures determined by the parameters of the habitat and the genetic diversity status of the species.

The objective of this paper was to relate the specificity of the occurrence of the glacial relic Betula humilis Schrank in the peatlands of Central-Eastern Poland, which developed under moderate climate conditions, to habitat conditions determined through the analysis of the physical-chemical parameters of groundwater and the species composition of phytocoenoses. The obtained information will also expand knowledge on the issue and strategy of the active protection of the species through the determination of ranges of fluctuations in habitat parameters, and the most optimal conditions for the implementation of a strategy to ensure its survival in the peatlands of Central-Eastern Poland.

\section{Materials and Methods}

Betula humilis Schrank in Central Europe is a boreal late-glacial relic from the family of birch/beech plants (Betulaceae). In terms of life form, it is a nanophamerophyte, a strongly branched bush, usually low, but reaching even $2.5-4 \mathrm{~m}$ in height. It has wart-like shoots rising up, and red-brown bark. The leaves are elliptical, round or egg-shaped, corrugated, light green on both sides, and have 4-5 pairs of lateral nerves. The blossom is bunched in short-stemmed, flaccid, and separately hanging inflorescences, or catkins, with male catkins (with a length of up to $20 \mathrm{~mm}$ ) and female catkins (with a length of $8-15 \mathrm{~mm}$ ). Shrub birch is a monoecious tree, pollinated by wind, with wind-borne seeds. It reproduces mainly generatively, but also vegetatively and is characterised by a polycormonal type of growth (multi-ramets). On many sites of occurrence it blossoms and bears fruit; the fruit is a winged nut. The flowering period is in May, and the seeds are spread in the autumn-winter season [10,15-17].

Shrub birch occurs in Eastern Europe, Siberia, and North-West Mongolia. The presence of scarce populations of $B$. humilis in the Alps, Carpathians, and Northern Germany suggests its broader range in the past [16,18-20].

Populations of shrub birch in Poland are particularly concentrated in West Pomerania, Masurian Lakeland, Podlasie, and Polesie $[16,17,19,20]$. Scarce populations were also encountered in Mazowsze, 
Ziemia Lubuska, and Małopolska [21]. Therefore, the south-western boundary of the compact range of the population of shrub birch runs through Poland (Figure 1) [18-20].

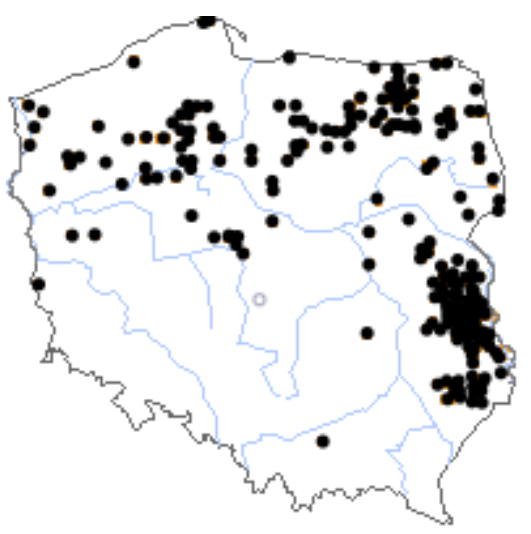

Figure 1. Range of occurrence of shrub birch in Poland based on $[19,20]$.

In terms of habitat, shrub birch is a subcontinental species preferring sites on organogenic, poorer soils, as well as those that are more abundant in nutrients, wet, and rather neutral in terms of acidity, with moderate light conditions, related to the Holarctic element and the Eurosiberian subelement [22].

Unfortunately, shrub birch has been retreating from its occupied sites for a long time [22]. Therefore, in 1983, it was covered by strict species protection [23], although attention was already drawn to the need for protection of the taxon 10 years earlier [24]. Due to the progressing degradation of the sites of occurrence and the limited population of B. humilis, it has the status of an endangered species (EN) in the Polish Red Book of Plants [17], and the status of a vulnerable species (V) in the study entitled Rare and Endangered Species of West Polesie [25] and in the Red List of Plants and Fungi of Poland [26].

Habitat research concerning shrub birch was conducted on peatlands of the central part of East Poland in Polesie Podlaskie. For the purpose of the determination of the specifics of its occurrence, based on reconnaissance (field and laboratory) research and desk studies (source materials), six study sites were designated, related to different quantities of occurrence of Betula humilis. They were lake-peatland complexes, namely Lake Moszne (M), Lake Długie (D), Lake Karaśne (K), Lake Bikcze (B), and Lubowierz Wilderness (L), as well as the Dekowina peatland complex (DK) (Figure 2).

At all of the study sites, research polygons were designated with a surface area dependent on the topographic-habitat conditions, ranging from 100 to $625 \mathrm{~m}^{2}$. They were strategically differentiated in terms of abundance of Betula humilis, measured by the percent contribution of its individuals to the plant assemblage, based on the degree of coverage of the studied area (from 5\% to $15 \%$ share in phytocenosis, as representative of the different peat bogs sites of shrub birch in the region of Central-Eastern Poland). The aspect of interspecific interactions was omitted. Considering their effect on the condition of the population of the analysed species, however, it was arbitrarily assumed to be the same for all sites.

For the purpose of sampling the peatland water, ground piezometers were dug in the central part of the sites (perforated PVC pipe with a diameter of $10 \mathrm{~cm}$ and length of $1 \mathrm{~m}$, closed with a lid). In the years 2011-2014, for seven terms each year in the vegetative season, laboratory analyses of the sampled piezometer water were performed. The analyses employed methods certified at the Central Agroecological Laboratory of the University of Life Sciences in Lublin (CLA). They covered 14 physical-chemical parameters of peatland waters: reaction $(\mathrm{pH})$, electrolytic conductivity (EC), dissolved organic carbon (DOC), content of phosphorus fractions: total phosphorus $(\mathrm{TP})$, phosphates $\left(\mathrm{P}-\mathrm{PO}_{4}\right)$, content of nitrogen fractions: total nitrogen (TN), ammonium nitrogen 
$\left(\mathrm{N}-\mathrm{NH}_{4}\right)$, nitrates $\left(\mathrm{N}-\mathrm{NO}_{3}\right)$, nitrites $\left(\mathrm{N}-\mathrm{NO}_{2}\right)$, and the mean concentration of sulphates $\left(\mathrm{S}-\mathrm{SO}_{4}\right)$ and basic cations: potassium $(\mathrm{K})$, sodium $(\mathrm{Na})$, calcium $(\mathrm{Ca})$, and magnesium $(\mathrm{Mg})$.

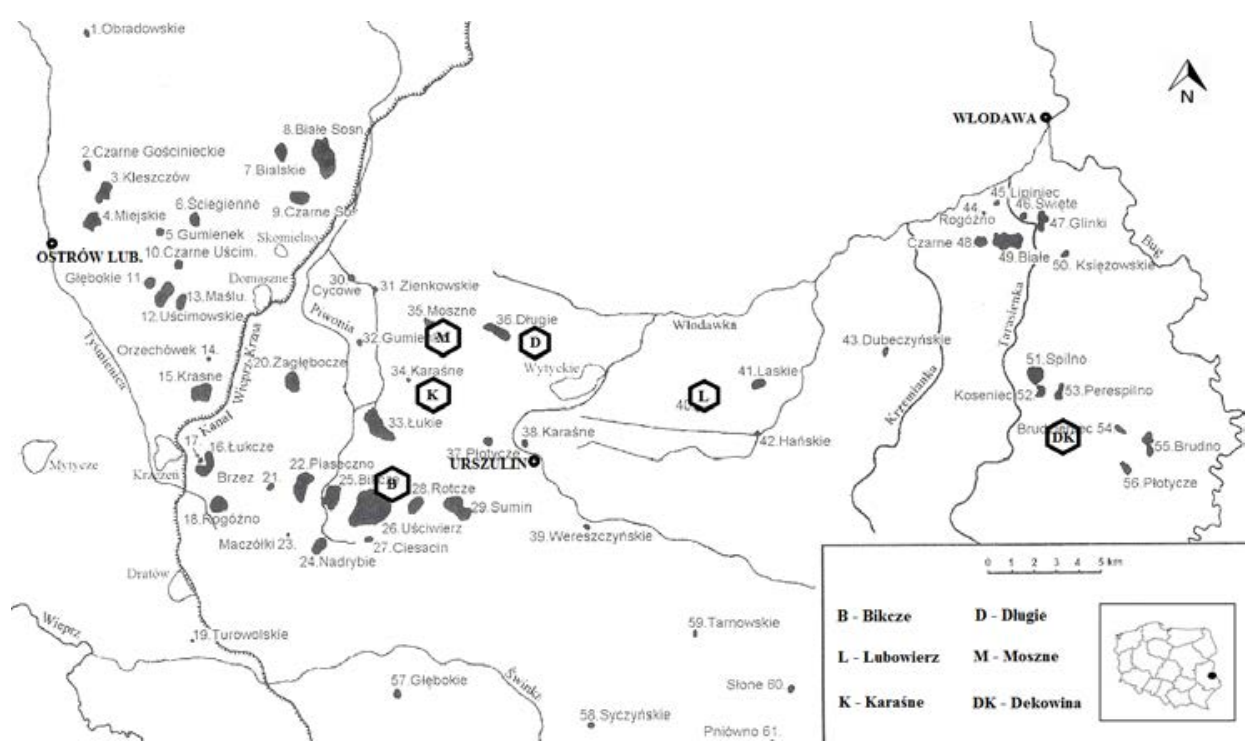

Figure 2. Location of the study sites in the Polesie Podlaskie Region based on [27].

The habitat research was supplemented with botanical analyses of the species composition of the phytocoenoses of the analysed surfaces, for which the per cent contribution of particular plant species was averaged for each site. Ecological coefficients of their species similarity were calculated following Jaccard [28]. In order to estimate the naturalness of plant communities, the species were assigned to historical-geographical and range groups, and anthropogenic changes in the flora, articulated by the following ecological indices:

total synanthropisation:

$$
\left(W_{S-c}\right)=\frac{A p+A}{S p+A} \times 100 \%
$$

total anthropophytisation:

$$
\left(W_{A n-c}\right)=\frac{A}{S p+A} \times 100 \%
$$

and total apophytisation:

$$
\left(W_{A p-c}\right)=\frac{A p}{S p+A} \times 100 \%
$$

Where $A p$-apophytes (taxa of synantropic plants of local origin, constituting part of the native flora, occurring in anthropogenic habitats developed as a result of human activity; $S p$-spontaneophytes (taxa developed in a given area or imported, able to function with no human interference, existing of nature) + apophytes, $A$-anthropophytes (taxa developed in a given area as a result of human pressure, taxa imported to a given area by man, and species surviving at sites under constant human pressure) devised by Chmiel $[29,30]$.

The results of the laboratory and botanical research were subject to the statistical analyses of the distribution of the parameters for the designated sites. In the case of the values of the analysed physical-chemical parameters, the lack of normality of the distribution was determined, as well as the non-uniform character of their variance. Therefore, further distribution analysis employed the 
non-parametric Kruskal-Wallis test and pairwise Wilcoxon rank sum tests. The basic descriptive statistics of the distribution of the analysed parameters are presented in the form of box diagrams, additionally including the p-value obtained as a result of testing.

Subsequently, we conducted a multivariate analysis, including classification and ordination. The hierarchical classification analyses were developed both based on the study sites and for the species composition using the complete linkage classification algorithm (for sites) and Ward's method (for species) with Jaccard's coefficient as a similarity measure.

To choose between linear and unimodal ordination, detrended correspondence analysis (DCA) was performed. The output of the DCA showed that the gradient length in all of the axes was smaller than 2. Therefore, redundancy analysis (RDA) was used to determine relationships between the species composition and selected physical-chemical peatland water parameters at the study sites. All statistical analyses were performed by means of the open source software R, version 3.4-3 [31] using packages: vegan (ver. 2.4-6) [32], nortest (ver. 1.0-4), MASS (ver. 7.3-50), and ggdendro (ver. 0.1-20).

\section{Results}

The methods for the selection of the study areas, as well as the designated sites, determined the different per cent contribution of B. humilis to the phytocoenoses of the study areas. More abundant populations of the species occurred in the peatland complexes at Karaśne (15\% contribution) and Bikcze ( $10 \%$ contribution). In the remaining locations, namely Moszne, Długie, Lubowierz, and Dekowina, the contribution of $B$. humilis to the phytocoenoses was somewhat lower, reaching $5 \%$ of the flora of the sites.

In assemblages of all study sites, a total of 43 species of seed-bearing plants from 23 botanical families were identified, with different phytocoenotic configurations. Species constantly accompanying shrub birch, although with varied percent contributions, included: Betula pubescens, Carex lasiocarpa, Comarum palustre, Menyanthes trifoliata, Oxycoccus palustris, and Salix cinerea.

The calculated coefficient of the Jaccard's species similarity of the analysed phytocoenoses was within a range from 0.32 (Blizionki-Lubowierz, B-L) to 0.6 (Karaśne-Dekowina, K-D), rarely and inconsiderably exceeding the threshold value of 0.5 (K-D, B-K, M-DK, L-DK). In spite of the typological similarity of the habitats, this suggests a diversity of flora within the study sites. The highest mean value of the Jaccard similarity coefficient was recorded for the phytocoenosis of site Karaśne (K) in comparison to the phytocoenoses of the remaining sites (mean 0.49). The remaining mean values of the analysed coefficient of comparable phytocoenoses did not exceed the threshold of 0.43 .

The classification analysis with the Jaccard coefficient as the measure of similarity, performed both for the sites and the species, provides more complete statistical information. A hierarchical agglomerative cluster analysis was conducted to identify the sites/species that were most similar to one another within each group. A combination of the Jaccard coefficient as a distance measure and the complete linkage method was used for clustering.

The species similarity dendrogram of the study sites determined the division into three clusters with a different degree of hierarchical similarity: Karaśne (K); Lubowierz, and Dekowina (L + DK), as well as Bikcze, Długie, and Moszne $(B+D+M)$. The Karaśne peatland complex is related to a eutrophic lake disappearing due to the intensified processes of ecological succession, and is characterised by the highest contribution of Betula humilis in the phytocoenosis. At a greater degree of generality, it shows species similarity to other study sites. The sites Lubowierz and Dekowina, which are not directly adjacent to water bodies, are characterised by a more considerable mutual species similarity, and are lower in comparison to the remaining groups. The cluster Bikcze, Długie, and Moszne covers sites in typologically similar lake-peatland complexes, which are therefore expectedly similar in terms of biocoenotic composition (Figure 3).

The dendrogram plot of the frequency of the common occurrence of the identified plant species in the phytocoenoses of the study sites shows two basic groups divided into smaller subgroups depending on the degree of hierarchical ordering (Figure 4). 
Group I includes 14 plant species: Calla palustris, Carex acutiformis, Carex elata, Carex limosa, Dactylorhiza incarnata, Eriophorum vaginatum, Lysimachia thyrsiflora, Lythrum salicaria, Potentilla erecta, Ranunculus lingua, Rhynchospora alba, Salix myrtilloides, Stellaria palustris, and Typha latifolia (Figure 4). They are closely related to ombrogenic habitats of high and transitional bogs, and in phytosociological terms they particularly occur in phytocoenoses from the classes Scheuchzerio-Caricetea, Alnetea glutinosae, and Oxycocco-Sphagnetea [33]. Group II includes the remaining 29 plant species (names of the species described in Figure 4), with similar phytosociological affinity, including Betula humilis, usually accompanied by Salix cinerea, Menyanthes trifoliata, Oxycoccus palustris, Betula pubescens, Carex nigra, and Carex rostrata (Figure 4), species frequently occurring on transitional bogs, particularly from the class Scheuzerio-Caricetea fusce [33].

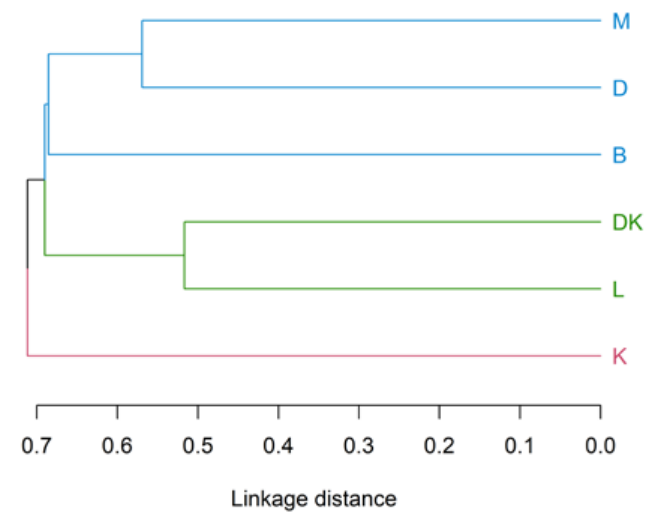

Figure 3. Dendrogram plot for sites. M-Moszne, D-Długie, B-Bikcze, DK-Dekowina, L-Lubowierz, K-Karaśne.

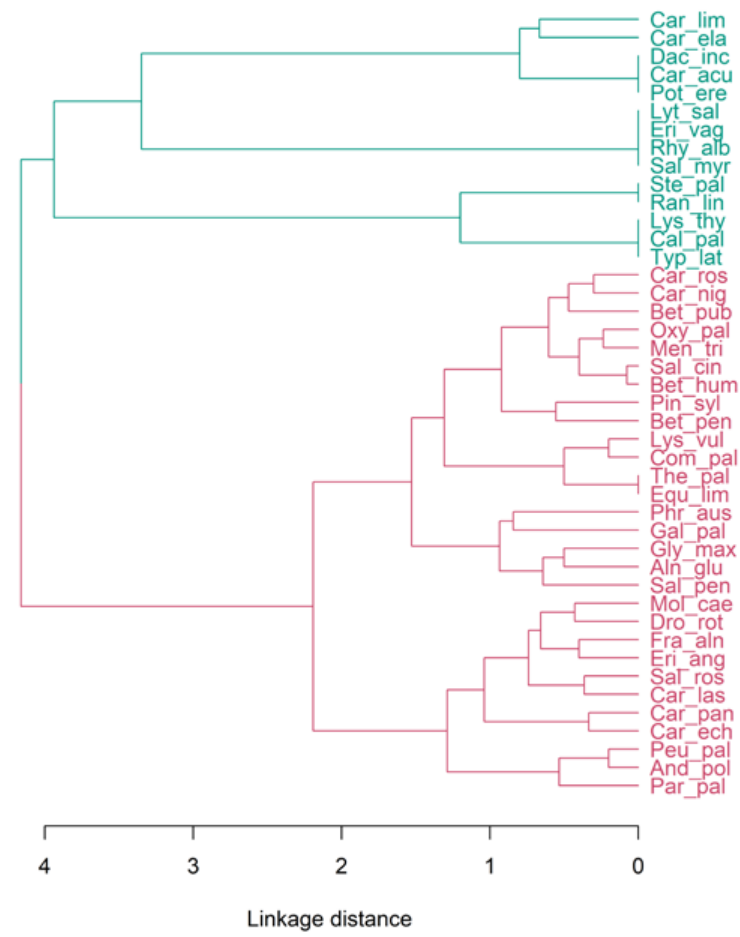

Figure 4. Dendrogram plot for species composition (taxonomic abbreviations from the first three letters of names of the genus and species of plants). Species composition of phytocoenoses (in alphabetical order): Alnus glutinosa, Andromeda polifolia, Betula humilis, Betula pendula, Betula pubescens, Calla palustris, Carex acutiformis, Carex echinata, Carex elata, Carex lasiocarpa, Carex limosa, Carex nigra, Carex panacea, 
Carex rostrata, Comarum palustre, Dactylorhiza incarnata, Drosera rotundifolia, Equisetum limosum, Eriophorum angustifolium, Eriophorum vaginatum, Frangula alnus, Galium palustre, Glyceria maxima, Lysimachia thyrsiflora, Lysimachia vulgaris, Lythrum salicaria, Menyanthes trifoliata, Molinia caerulea, Oxycoccus palustris, Parnassia palustris, Peucedanum palustre, Phragmites australis, Pinus sylvestris, Potentilla erecta, Ranunculus lingua, Rhynchospora alba, Salix cinerea, Salix myrtilloides, Salix rosmarinifolia, Salix pentandra, Stellaria palustris, Thelypteris palustris, Typha latifolia.

In species and phytosociological terms, the analysed phytocoenoses are therefore typical of selected characteristic peatland habitats in the moderate climate of the central part of East Poland $[3,22,34]$.

Due to the lack of anthropophytes $(A)$ among the identified species, and due to the scarce representation of apophytes $(A p)$, synantropisation indices of the flora defined as a change in the species composition of phytocoenoses as a result of human pressure suggested the exceptional naturalness of the selected study sites. The indices of the anthropophytisation of flora $\left(W_{A n-c}\right)$ and the synantropisation of flora $\left(W_{S-c}\right)$ adopted the value of 0 for all sites, whereas the values of the index of the apophytisation of flora $\left(W_{A p-c}\right)$ varied from 0 (sites $\mathrm{K}$ and $\mathrm{D}$ ) to $12.5 \%$ (site-L). Therefore, the obtained indices of changes in the flora did not confirm the considerable impact of human pressure on the biocoenotic status of representative habitats of shrub birch in the Polesie Podlaskie region.

A more complete image of the habitat preferences of Betula humilis with reference to the state of the environment is provided by the values of the physical-chemical parameters analysed in the groundwater in the years 2011-2014 (Figure 5).

Fluctuations of the parameters based on the variable per cent contribution of the studied species to the phytocoenoses of the selected habitats determined the range of its ecological tolerance in reference to the analysed parameters and region of its occurrence (Figure 5).

The first stage of the study involved the analysis of the empirical distribution of the physical-chemical parameters of the pooled data.

Due to considerable deviations in part of the results, the mean values of the majority of the parameters (e.g., EC, DOC, $\mathrm{Na}, \mathrm{Ca}, \mathrm{TN}, \mathrm{S}-\mathrm{SO}_{4}$ ) exceeded the range of a typical distribution of observations, resulting in a somewhat misleading image of the intensity of a given parameter (Figure 5). The values, however, did not exceed the range typical for habitats appropriate for the implementation of the life strategy of the species, although they sometimes exceeded the optimum for the species $[20,22,34]$.

Depending on the study site, a divergence of some habitat parameters was observed (i.e., $\mathrm{Mg}$, $\mathrm{Ca}, \mathrm{pH}, \mathrm{EC}, \mathrm{DOC}, \mathrm{TP}, \mathrm{TN}$, and to a lower degree $\mathrm{P}_{-} \mathrm{PO}_{4}$ and $\left.\mathrm{N}-\mathrm{NH}_{4}\right)$, increasing the amplitude of ecological tolerance for the studied species in the area of the peatlands of East Poland (Figure 6).

For the Karaśne $(\mathrm{K})$ site, with the highest per cent contribution of Betula humilis to the phytocoenosis, higher values in comparison to other sites were recorded for $\mathrm{pH}, \mathrm{EC}$, and $\mathrm{Ca}$. In the case of TN, $\mathrm{N}-\mathrm{NH}_{4}$, and $\mathrm{DOC}$, their values at the Karaśne site were approximate to the values determined for the Bikcze (B), Długie (D), and Moszne (M) sites, and lower in reference to the Dekowina (DK) and Lubowierz (L) sites. In the case of fractions of phosphorus, similar values were observed particularly at sites $\mathrm{K}, \mathrm{D}$, and $\mathrm{M}$, these were higher for the remaining sites. For potassium, approximate values were determined for sites $\mathrm{K}, \mathrm{B}, \mathrm{M}$, and L, slightly higher values were observed in the case of site DK, with somewhat lower values for site $\mathrm{D}$. The values of the $\mathrm{Mg}$ ions at the Karaśne site were comparable to those at the Bikcze site, and in the case of the remaining sites they were lower. Other analysed physical-chemical parameters of the habitat, i.e. $\mathrm{Na}, \mathrm{S}_{-} \mathrm{SO}_{4}, \mathrm{~N}-\mathrm{NO}_{2}$, and $\mathrm{N}-\mathrm{NO}_{3}$, had comparable values at all study sites (Figure 6), therefore they had no limiting importance for the abundance of the B. humilis population.

The above observations are confirmed by the $p$-value from the Kruskal-Wallis test (Figure 6), where at the significance level of $p<0.05$, considerable differences were determined in the distribution of nine parameters, $\mathrm{TN}, \mathrm{N}-\mathrm{NH}_{4}, \mathrm{TP}, \mathrm{P}-\mathrm{PO}_{4}, \mathrm{DOC}, \mathrm{pH}, \mathrm{EC}$, as well as $\mathrm{Mg}$ and $\mathrm{Ca}$ in reference to six 
sites subject to the analysis (Table 1 ). The distribution of the remaining parameters: $\mathrm{Na}, \mathrm{K}, \mathrm{N}-\mathrm{NO}_{2}$, $\mathrm{N}-\mathrm{NO}_{3}$, and $\mathrm{S}-\mathrm{SO}_{4}$ did not differ significantly.
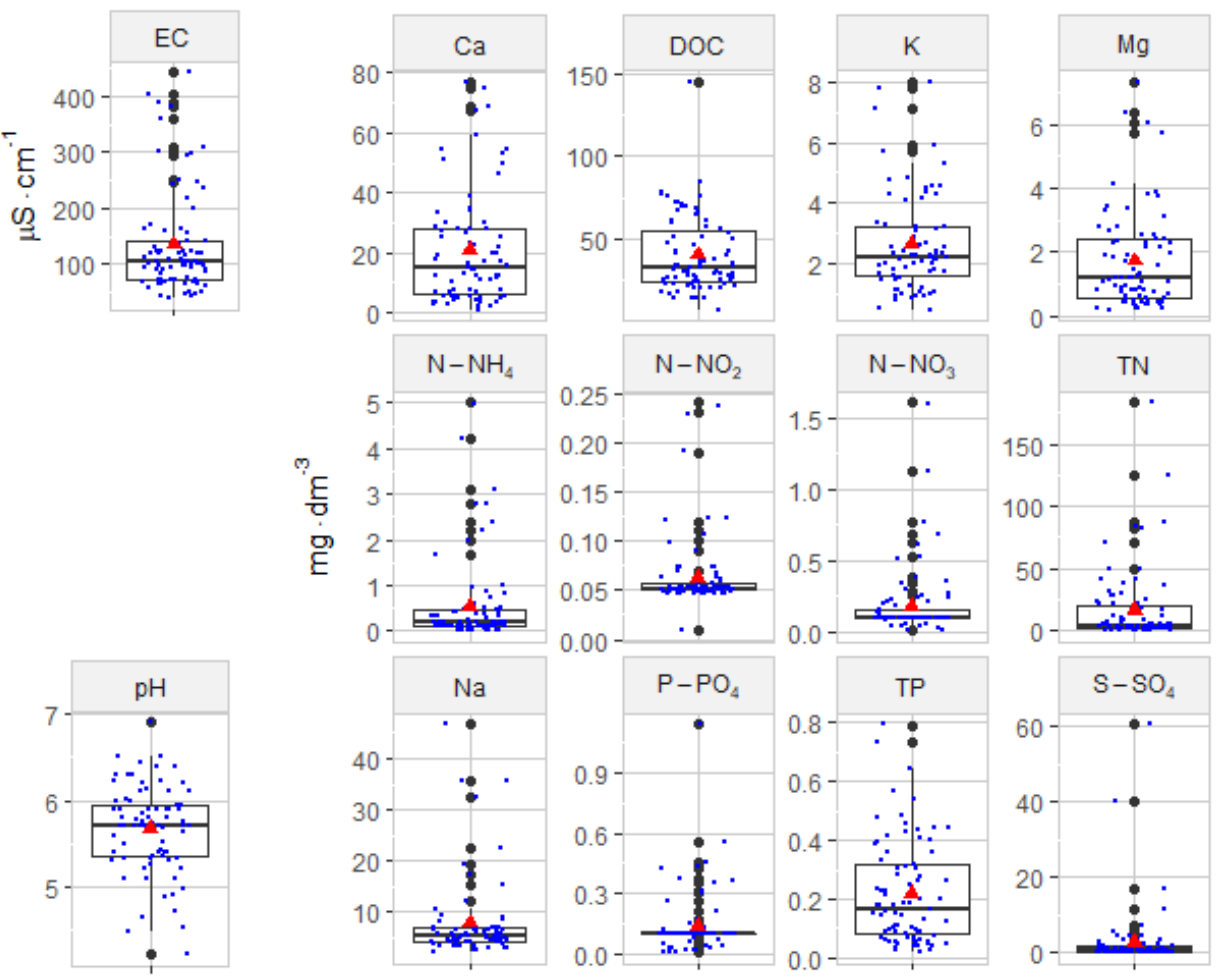

Figure 5. Distribution of the values of the investigated physical-chemical parameters of piezometric groundwater at the study sites in the years 2011-2014. The box-and-whisker plots show the distribution of the observations. In particular, the box represents the first and third quartiles. The horizontal line across the central region of the box represents the median. The mean value of the data is marked by a red filled triangle. The whiskers are drawn to the most extreme observations located no more than 1.5 times the inter-quartile range away from the box. Any observation not included between the whiskers is considered as an outlier and is plotted with a filled circle. When there are no outliers, the whiskers indicate the minimum and maximum values. The plot presents observed values of particular parameters, marked with blue dots.
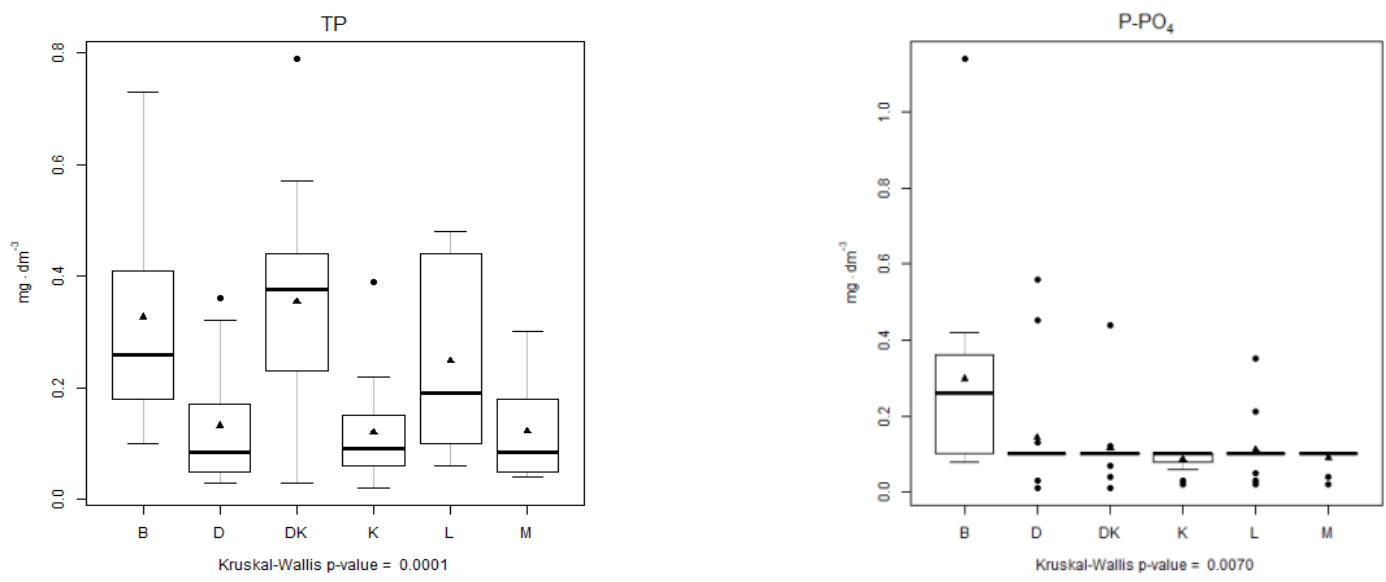

Figure 6. Cont. 

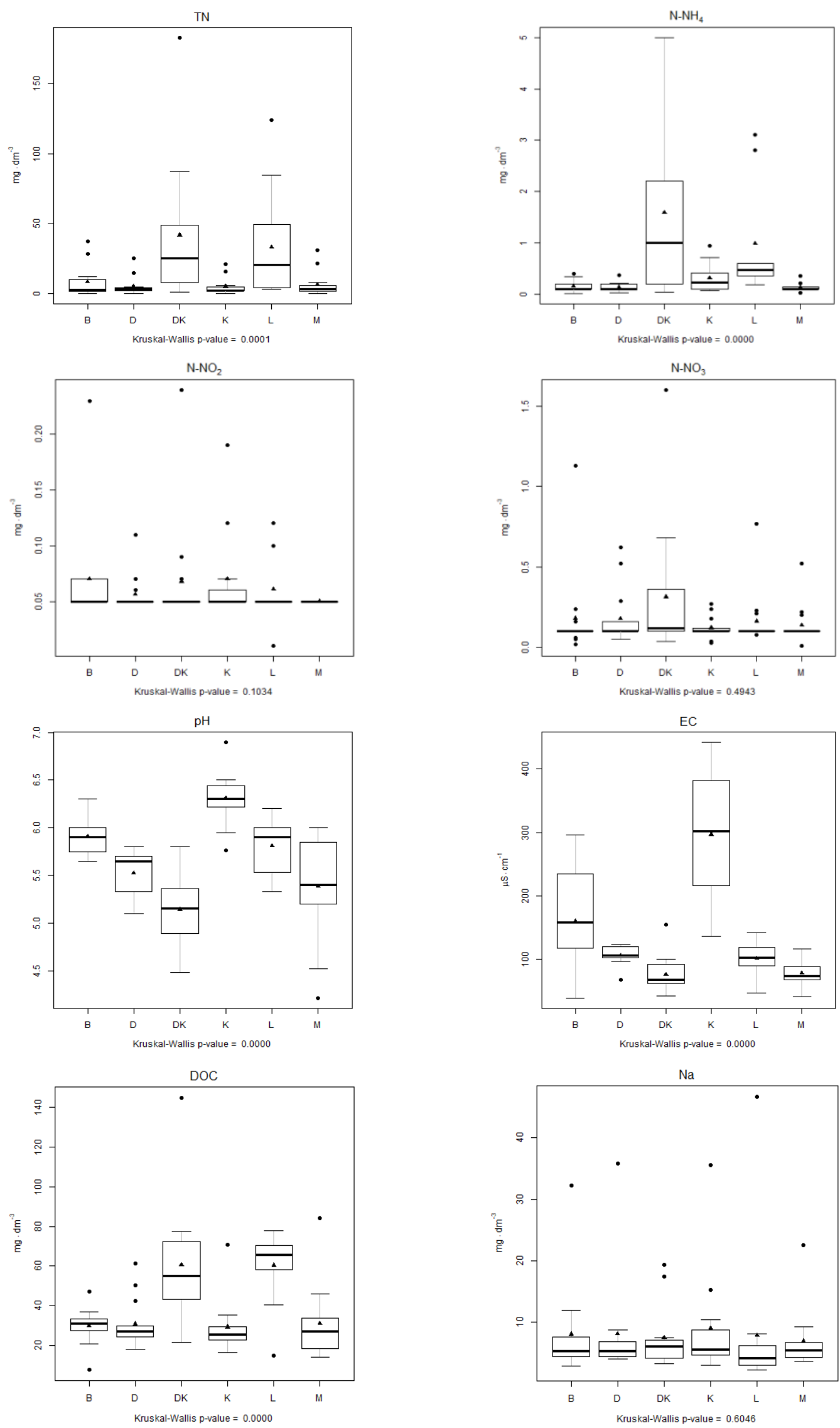

Figure 6. Cont. 

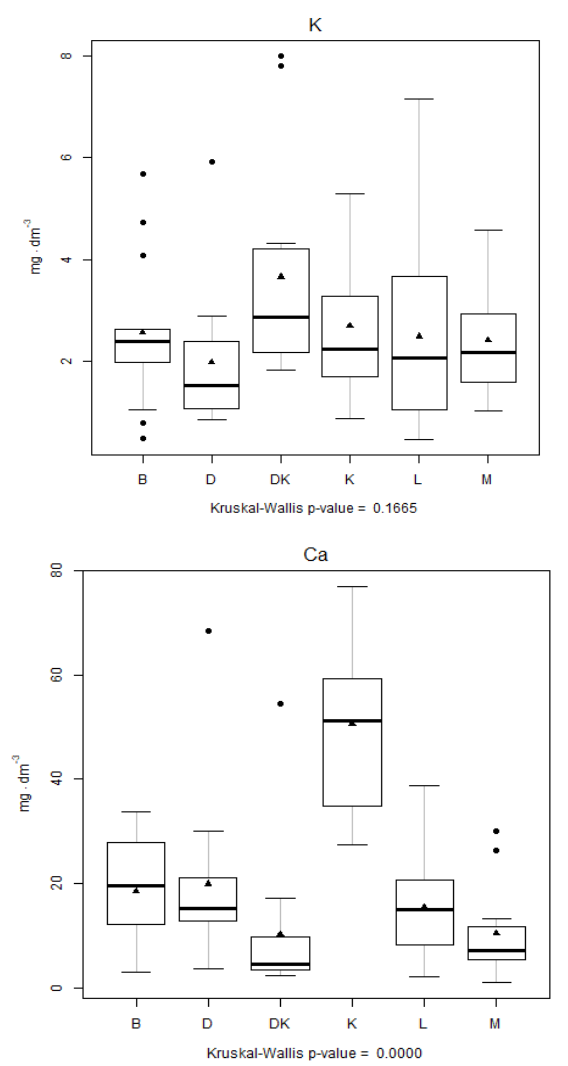
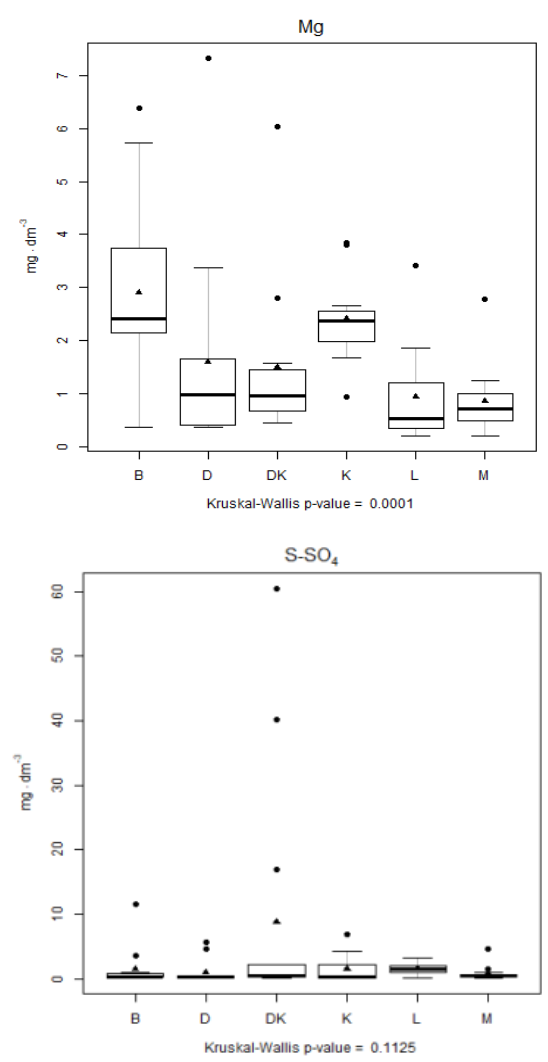

Figure 6. Distribution of the values of the investigated physical-chemical parameters of piezometric groundwater at six study sites in the period 2011-2014. The $\mathrm{x}$ axis label provides the $p$-value derived by the Kruskal-Wallis test. The horizontal line across the central region of the box represents the median. The mean value of the data is marked by a filled triangle. Any observation not included between the whiskers is considered an outlier and is represented by a filled circle.

Subsequently, pairwise comparisons between groups of sites with Bonferroni correction for multiple testing were calculated (Table 1). The lowest number of significant differences at a significance level of 0.05 were observed for the values of the analysed parameters in the comparison of sites D-M, DK-L, DK-M, and K-M, and the highest number were observed for the following comparisons B-DK, B-L, D-DK, and K-L (Table 1).

Table 1. Values of the Kruskal-Wallis test statistics, $p$-values and results of multiple comparisons for significantly variable parameters at particular study sites. Column I presents the type of the analysed parameter, column II of the table includes values of the obtained test statistics, column III includes the corresponding $p$-values. Results of multiple comparisons are presented in column IV, sites for which significant differences were obtained at a significance level of 0.05 are marked with a colour. Parameters $\mathrm{S}_{-} \mathrm{SO}_{4}, \mathrm{~N}-\mathrm{NO}_{2}, \mathrm{~N}-\mathrm{NO}_{3}, \mathrm{~K}$, and $\mathrm{Na}-$ no significant differences.

\begin{tabular}{|c|c|c|c|c|c|c|c|c|c|c|c|c|c|}
\hline \multirow{2}{*}{$\begin{array}{l}\text { Analysed } \\
\text { Parameter }\end{array}$} & \multirow{2}{*}{$\begin{array}{c}\text { Kruskal-Wallis } \\
\chi^{2} \text { Statistic }\end{array}$} & \multirow{2}{*}{$p$-Value } & \multicolumn{11}{|c|}{ Multiple Comparison Test, Kruskal-Wallis Test } \\
\hline & & & B-D & B-DK B-K & B-L & B-M & D-DK D-K & D-L & D-M & DK-K DK-L & DK-M K-L & K-M & L-M \\
\hline I & II & III & \multicolumn{11}{|c|}{ IV } \\
\hline TN & 26.543 & $6.999 \times 10^{-5}$ & & & & & & & & & & & \\
\hline $\mathrm{TP}$ & 27.115 & $5.419 \times 10^{-5}$ & & & & & & & & & & & \\
\hline $\mathrm{N}-\mathrm{NH}_{4}$ & 31.095 & $8.969 \times 10^{-6}$ & & & & & & & & & & & \\
\hline $\mathrm{P}-\mathrm{PO}_{4}$ & 15.951 & 0.006984 & & & & & & & & & & & \\
\hline $\mathrm{pH}$ & 50.385 & $1.156 \times 10^{-9}$ & & & & & & & & & & & \\
\hline DOC & 31.313 & $8.124 \times 10^{-6}$ & & & & & & & & & & & \\
\hline EC & 47.465 & $4.566 \times 10^{-9}$ & & & & & & & & & & & \\
\hline $\mathrm{Mg}$ & 25.025 & 0.0001378 & & & & & & & & & & & \\
\hline $\mathrm{Ca}$ & 33.986 & $<0.001$ & & & & & & & & & & & \\
\hline
\end{tabular}


The next stage of the statistical analysis involved methods of direct ordination. Based on the results of the detrended correspondence analysis (DCA, SD $<2$ ), the redundancy analysis (RDA) was performed. The calculations considered six sites and 43 plant species. Due to the relatively low number of sites in comparison to the number of all the analysed physical-chemical parameters, the set of selected significant parameters was also limited [35,36]. A two-stage selection procedure was implemented for the environmental data. At the first stage, statistically insignificant variables were excluded (Kruskal-Wallis test results were taken into account at the significance level $p<0.05$ ), which limited the set of variables to TN, N-NH $4, \mathrm{TP}, \mathrm{P}-\mathrm{PO}_{4}, \mathrm{DOC}, \mathrm{EC}, \mathrm{pH}, \mathrm{Mg}$, and Ca. At the second stage, highly correlated variables were removed using a test of significance for a Pearson correlation coefficient. Values of the calculated correlation coefficients and test results are presented as a correlation matrix (Figure 7). Notice a strong positive correlation between the following parameters, TN with $\mathrm{N}-\mathrm{NH}_{4} ; \mathrm{EC}$ with $\mathrm{pH}$ and $\mathrm{Ca}$, and positive correlation between TP and $\mathrm{P}_{-} \mathrm{PO}_{4}$. Moreover, a weaker correlation, that is statistically different from 0 , is observed between $\mathrm{Mg}$ and $\mathrm{TP}, \mathrm{P}-\mathrm{PO}, \mathrm{Ca}, \mathrm{EC}$, and $\mathrm{pH}$ (Figure 7).

Due to this, the RDA analysis eventually covered four parameters: TN, TP, $\mathrm{pH}$, and DOC. Prior to the analysis, environmental variables were standardised to zero mean and unit variance [37].

\begin{tabular}{|c|c|c|c|c|c|c|c|c|}
\hline $\mathrm{TN}$ & & & & & 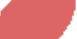 & & & \\
\hline $0.81^{*}$ & $\mathrm{~N}-\mathrm{NH}_{4}$ & & & & & & & \\
\hline $0.48^{*}$ & $0.45^{*}$ & TP & & & & & & \\
\hline 0.18 & 0.09 & $0.54^{*}$ & $\mathrm{P}-\mathrm{PO}_{4}$ & & & & & \\
\hline-0.17 & -0.14 & -0.15 & 0.04 & $\mathrm{pH}$ & & & & \\
\hline $0.47^{*}$ & $0.37^{*}$ & $0.34^{*}$ & -0.02 & -0.19 & $\mathrm{DOC}$ & & & \\
\hline-0.21 & -0.14 & -0.15 & -0.01 & & $-0.24^{*}$ & EC & & \\
\hline 0.13 & 0.08 & $0.5^{*}$ & $0.36^{*}$ & $0.29^{*}$ & -0.03 & $0.34^{*}$ & $\mathrm{Mg}$ & \\
\hline-0.06 & 0.02 & 0.03 & -0.03 & $0.55^{*}$ & -0.11 & $0.74^{*}$ & $0.61^{*}$ & $\mathrm{Ca}$ \\
\hline
\end{tabular}

Figure 7. Correlation matrix for the selected parameters preselected by the Kruskal-Wallis tests. The lower triangular part of the matrix contains Pearson correlation coefficients for each pair of variables specified on the diagonal. Correlation coefficients significantly different from 0 for $p<0.05$ are marked with an asterisk $\left(^{*}\right)$. The upper triangular part of the matrix contains the visualisation of correlation coefficients in the form of ellipses. The ellipse represents a level curve of the density of a bivariate normal with the matching correlation.

All the selected parameters explained $80.37 \%$ of the total variance. The first two RDA axes cover $58.69 \%$ of the total explained variance (RDA1: $51.45 \%$; RDA2: $20.16 \%$ ). The redundancy analysis results are visualised in triplot ordination diagrams (Figure 8 ) using two scaling methods (scaling = 1 and scaling = 2) [36]. In Figure 8a, the distances between the sites approximate Euclidean distances. Sites $B$ and $L$ can be expected to have similar environmental parameter values and species compositions. The selected environmental parameters are represented by vectors directed at the highest variance (Figure 8a). Sites D, M, and K are characterised by similar values (on the average level) for parameters 
TN as well as $\mathrm{pH}$ and DOC. The value of TP in the case of site D, however, is much lower than the average level, and in the case of site $\mathrm{K}$, above the average level. The remaining sites are characterised by the high variability of the analysed parameters. The positive part of the first axis RDA1 is correlated with the highest values of DOC. Concerning RDA2, its positive part is strongly correlated with the highest levels of TN and $\mathrm{pH}$. The second axis also showed that DOC and TP are correlated with its positive part with a similar magnitude (Figure 8).

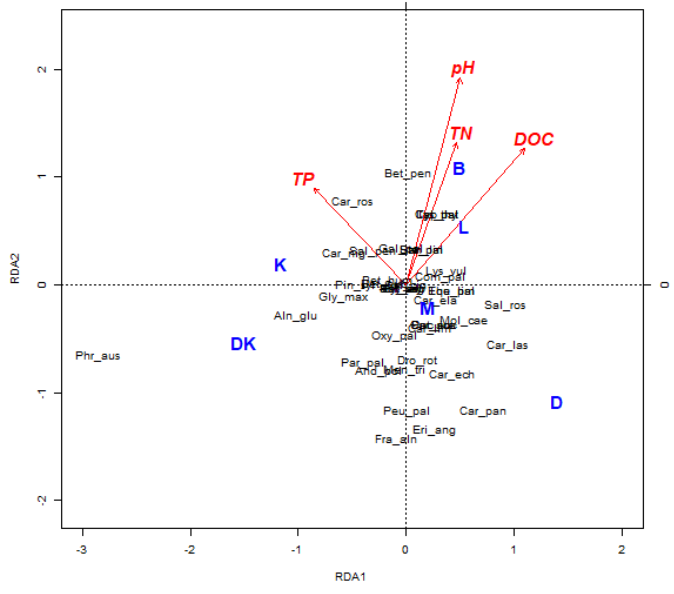

(a)

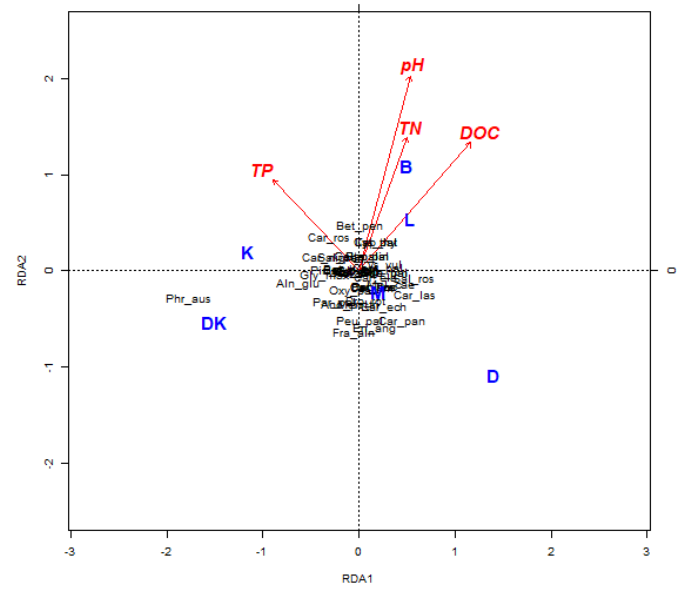

(b)

Figure 8. Ordination triplots of the first two axes (RDA1 and RDA2) generated from the redundancy analysis for six study sites, 43 species, and four environmental variables. (a) scaling = 1; (b) scaling = 2 .

\section{Discussion}

The basic subject of research into the habitats of populations of rare and endangered plant species is the analysis of the effect of the quality of the habitat on their structure and functioning [38-41]. The character of the research covers a number of different dependencies, e.g., susceptibility to the extinction of small isolated populations [42]; the heterogeneity of habitats and their effect on species richness, and the effect of the fragmentation of anthropogenic habitats on the number and state of rare plant species [14]; or the analysis of habitat indices with respect to attempts to actively protect such species $[8,9]$.

Among 418 species of vascular plants endangered in Poland, 55 (13\%) are peatland plants, including Pleistocene boreal relics [26]. Although similarly to other rare plants they often reach a small per cent contribution to peatland phytocoenoses, they play an important role in their functioning [43].

\subsection{Anthropogenic Impacts in the Region}

Global (climatic) and local (e.g., hydrological relations, eutrophication) anthropogenic transformations of habitat conditions prevail over the adaptation possibilities of Pleistocene relics in spite of their anatomical and physiological adaptations to life in difficult conditions [10-12].

Disturbances of the hydrological regime, changes in the rate of biogenic accumulation and fluctuations of the groundwater table, acid rain, the introduction of toxic and hazardous substances, the eutrophication of oligotrophic habitats resulting from the intensification of agricultural production, the development of road transport, industrialisation, urbanisation, unorganised tourism, etc., cause the degradation and fragmentation of habitats of many rare plant species $[13,14]$, including a number of peatland species $[6,11]$.

The majority of analogical, indirect and direct anthropogenic transformations affecting the habitat conditions of water and peatland ecosystems concern the central part of East Poland, Polesie Podlaskie [44-46]. The primary threat to the existence and functioning of peatland ecosystems in the 
area, however, is associated with changes in hydrological relations. They are related to meliorations generating a decrease in the groundwater table; the functioning of the Wieprz-Krzna Channel system, responsible for the hydrotechnical remodelling of lakes and rivers, and causing the introduction of alien waters to the ecological system of the peatlands [47,48]; as well as the local impact of the Lublin Coal Basin. The regulation of river channels, digging drainage ditches, and the incorporation of lakes into the drainage network have been affecting the state of peatland habitats in the area since the middle of the 19th century. Only the construction (1954-1961) and operation of the draining Wieprz-Krzna Channel, including the transformation of several lakes into retention reservoirs, caused an increase in the rate of water outflow and a decrease in the groundwater level in Polesie Podlaskie by an average of $50-80 \mathrm{~cm}$. Moreover, the discussed channel contains waters with a chemical specification alien to the region, contributing to changes in the habitat conditions of local peatlands [49-51]. The functioning of the Lublin Coal Basin can also have an indirect effect on the hydrological state of Polesie Podlaskie. Coal extraction from deposits at a depth of $1 \mathrm{~km}$ results in breaking through aquifers. Due to the hydraulic connections of parts of fossil deposits with overlying waters, this causes outflow, the elimination of surface stagnation, and a decrease in natural water retention $[8,9,52]$.

A consequence of water relations in peatland ecosystems related to the draining of peat deposits is the mineralisation of organic matter. Similarly to the inflow of allogenic, and particularly eutrophic waters, it determined changes in habitat conditions, and therefore a qualitative transformation of the biocoenotic composition of phytocoenoses.

The initial decrease in the groundwater table contributed to an acceleration of transformations related to the ecological succession and transformation of peatland turf ecosystems towards forest assemblages [53-55]. This results from the encroachment on peatlands of high growing tree species (e.g., Betula pendula, Betula pubescens, Salix aurita, Salix cinerea, or Salix pentandra) with considerable competitive abilities, and from the expanded assimilation apparatus, with a high evapotranspiration coefficient. This contributes to additional drainage of the peatland, and intensifies succession processes. The effect of such transformations on the peatlands of Polesie Podlaskie is therefore the loss of local sites of occurrence of plant species with reduced adaptation capacity, often Pleistocene boreal relics [6-9,56], which can be used as an indicator of progressing changes in habitat conditions. The confirmation of the phenomenon was presented already in 1987, when the loss of shrub birch sites in comparison to the state from the years 1947-1967 in the Lublin Region (East Poland) was determined to be $99 \%$ [19,57]. A similar decrease in the number of sites concerned other rare boreal species such as Salix lapponum $[6,7,9,22]$ or Salix myrtylloides $[5,8]$.

A phenomenon equally unfavourable for the functioning of the shrub birch population is a constantly high groundwater level. Although this limits the succession of trees, it exceeds the ecological optimum of the studied species, which prefers somewhat more drained habitats $[19,20]$. Frequent fluctuations of peatland water levels are similarly unfavourable for the analysed species. Periods of high water levels alternating with periods of considerable drying of the peatland negatively affect the state of health of Betula humilis, leading to its loss [58]. In the years 2011-2014, in the peatlands of Polesie Podlaskie, the level of peatland waters at the majority of the study sites was constantly average, approximate to the level of peat, and showed oscillations related to seasons of the year when higher water content was determined after snowmelt in the spring season, and a somewhat lower peatland water level in the summer period. A slightly lower level of peatland waters with a similar fluctuation amplitude was observed for the sites Dekowina (D) and Lubowierz (L), not directly related to the lake system. Therefore, peatland water level fluctuations could not be a limiting factor for the local populations of the studied species, at least in the study period. A lower level of peatland waters, below the peat level, however, could be a factor determining the low contribution of shrub birch to the phytocoenoses of sites $\mathrm{D}$ and $\mathrm{L}$, and depreciate the sites for potential future projects of restitution of the shrub birch population. 


\subsection{Botanical Analysis}

The biocoenotic composition of phytocoenoses, and therefore the presence of accompanying plants, is very important for the occurrence of rare and protected plants in naturally preserved habitats. During the research (2011-2014), at the sites of occurrence of Betula humilis, no remaining plants of species directly related to human activity, anthropohytes, were recorded in the species composition. Moreover, due to the scarce contribution of species with constant occurrence in anthropogenic habitats, apophytes, the calculated indices of the synantrophisation, anthropophytisation, and apophytisation of the flora showed the naturalness of all the habitats subject to the study. The site on Lake Karaśne (K), however, is the most natural in those terms. It is characterised by the lowest values of the calculated indices of changes in flora, and the highest abundance of individuals of the studied species.

The presence of different accompanying plant species determines the phytospciological dependencies. In these terms, Betula humilis occurs in phytocoenoses with different names and classifications, suggesting a lack of unambiguous determinations. According to the literature on the subject, concerning phytocoenoses with shrub birch in Polesie Podlaskie, in fens the said species develops its own assemblage Betuletum humilis, designated in the scope of assemblage Alnion glutinosae, taking the form of dense thickets dominated by shrub birch, with an admixture of Salix cinerea, S. rosmarinifolia, Betula pendula, and B. pubescens. In the herbaceous layer, the following species constantly occur Thelypteris palustris, Lycopus europaeus, Lythrum salicaria, Festuca rubra, and Molinia coerulea [59]. According to the more broadly applied classification of phytocoenoses with shrub birch [33], the species is one of characteristic species (alongside Salix rosmarinifolia) of the assemblage Betulo-Salicetum, standing out among other assemblages from the class Alnetea glutinosae due to a substantial contribution of species transitioning from the class Scheuchzerio-Caricetea nigrae. Both opinions are reflected in the research conducted in the years 2011-2014. The majority of the accompanying species, their per cent contribution to phytocoenoses, and the frequency of their common occurrence with Betula humilis on the study sites suggest both possibilities of phytosociological classification.

The presence of trees at the study sites, i.e. Alnus glutinosa, Betula pendula, Betula pubescens, Frangula alnus, Pinus sylvestris, Salix cinerea, Salix rosmarinifolia, or Salix pentandra, sometimes with a higher percent contribution to the phytocoenoses (5-15\%), suggests the intensification of ecological succession, and may affect the environmental parameters, determining its shading. Shrub birch as a photophilic species, similarly to other birches, is exceptionally sensitive to light conditions. It negatively responds to a reduced amount of light, which causes it to accelerate the growth of shoots in length, reduce branching, and almost completely eliminate blooming. The mechanism has been known and described for this type of plants for a long time [60]. It explains the fact of the rare occurrence of the species under the canopy of trees that contribute to its competitive replacement [19,20]. The resulting lack of possibility of generative reproduction considerably contributes to a decrease in the adaptation abilities of particular individuals, and determines the negative perspectives for the maintenance of local populations in reference to the rate and intensification of succession processes related to the overdrying of fens and transitional bogs in the Łęczna-Włodawa Lakeland.

\subsection{Analysis of the Physical-Chemical Parameters}

In the years 2011-2014, the habitat conditions determined by the values of the analysed physical-chemical peatland water parameters were characterised by sometimes considerable amplitudes and substantial differences between the sites of occurrence of shrub birch, as confirmed by the statistical analysis (K-W test). The most statistically significant differences occurred between sites more abundant in individuals of shrub birch (K-Karaśne, B-Bikcze) and the Dekowina (DK) and Lubowierz (L) sites, with a similar, lower per cent contribution of the studied species to the phytocoenoses, and concerned nine of the analysed physical-chemical parameters of peatland waters: $\mathrm{TN}, \mathrm{N}-\mathrm{NH}_{4}, \mathrm{TP}, \mathrm{P}_{-} \mathrm{PO}_{4}, \mathrm{DOC}, \mathrm{pH}, \mathrm{EC}$, as well as $\mathrm{Mg}$ and $\mathrm{Ca}$. In particular, the TP values $\left(\mathrm{mg} \cdot \mathrm{dm}^{-3}\right)$ were lower than other obtained values, in the range of: $0.08-0.32 ; \mathrm{P}^{-\mathrm{PO}_{4}}=0.1 ; \mathrm{TN}=2.2-21.2$; $\mathrm{N}-\mathrm{NH}_{4}=0.1-0.46 ; \mathrm{DOC}=24.6-55.9$. Higher $\mathrm{pH}$ values in the range of 5.34-5.95; and in $\mathrm{mg} \cdot \mathrm{dm}^{-3}$ 
$\mathrm{Ca}=5.67-28.1 ; \mathrm{Mg}=0.56-2.41$, and $\mathrm{EC}=72.1-142.3 \mu \mathrm{S} \cdot \mathrm{cm}^{-1}$ can be treated as a favourable condition for the proper development of the shrub birch population in Polesie Podlaskie. It is worth emphasising that the values are only partly within the ranges described in the literature as optimal for the development of shrub birch, i.e.: $\mathrm{pH}=7.0$; $\mathrm{EC}=300-400 \mu \mathrm{S} \cdot \mathrm{cm}^{-1} ; \mathrm{Ca}=10-30 \mathrm{mg} \cdot \mathrm{dm}^{-3}$, $\mathrm{Mg}=10-15 \mathrm{mg} \cdot \mathrm{dm}^{-3}[16,19,20]$. This probably results from the specificity of the habitats of peatlands in Central Eastern Poland, where the primary factor affecting biocoenotic systems are anthropogenic regulations of hydrological relations, and particularly improper melioration [61] causing a shift of the values of many habitat parameters towards the pessimum of the range of ecological tolerance of $B$. humilis. The analysis of the source materials $[62,63]$ also shows that shrub birch can belong to the species of habitat where the primary production is limited by phosphorus. The fertility gradient based on this element suggests the occurrence of more abundant $B$. humilis populations in the area of overdried peatlands in Central-Eastern Poland, with a lower value of phosphorus fractions in comparison to equivalent habitats in North Poland. This is probably related to the presence of soils rich in calcium hydroxides that absorb phosphates. In such conditions, also related to the relatively high and stable level of peatland waters, the development of competitive species such as high sedges, reeds, and trees is inhibited, and shrub birch has a chance of effective generative and permanent population growth [19,20]. Although research from the years 2011-2014 within the selected sites showed no correlations between $\mathrm{Ca}$ and $\mathrm{P}-\mathrm{PO}_{4}$, favourable values of the factors were determined for the development of the shrub birch population in accordance with the above assumption, namely higher values of $\mathrm{Ca}$ and lower than average values of $\mathrm{P}_{-} \mathrm{PO}_{4}$.

The obtained results show that shrub birch has a relatively broad range of ecological tolerance within particular areas of occurrence. Therefore, it cannot be a sensitive indicator of environmental changes. From the perspective of an assessment of the state of the environment, however, important habitat parameters exist affecting the specificity of its occurrence. These are, among others, the deregulation of water relations and the contribution of calcium hydroxides and phosphorus fractions. Therefore, the commonly adopted concept of the ecological and floristic variability of peatland vegetation based on habitat gradients, particularly concerning the water level, fertility, and alkali content [64], with reference to the occurrence of shrub birch in the peatlands of Central-Eastern Poland can be considerable reflected. Nonetheless, due to the specificity of the relations of the physical-chemical habitat parameters, the biocoenotic effects of habitat transformations can be somewhat shifted in time. This is of particular importance in the case of plans concerning the active protection of the species. Its effectiveness requires knowledge of its ecological requirements with reference to the habitat conditions selected for the restitution of sites. Therefore, the criterion of selection of the protection strategy for Betula humilis Schrank should be its maintenance in possibly approximate to natural, undisturbed habitat conditions, which should provide for the permanence of the population. The most important habitat parameters permitting the maintenance of its assemblages include the appropriate level of groundwater and chemical parameters of the habitat $[19,20]$. An important issue is also the analysis of the climate changes that are of global significance, exceeding the possible impact of pro-environmental projects particularly targeting regional and local components of the environment.

\subsection{Problems of the Active Protection of the Species}

The character of the active species protection of shrub birch should depend on the degree of anthropogenic transformation of the environment. It seems that in areas with a minimum impact of human economy, such as national parks and strict or partial reserves, or in exposed places with approximate to optimum chemical specifications of the peatland waters, in the case of abundant populations of shrub birch, the active protection of the species should be based on the regulation of water relations towards an increase in maintenance of the peatland water level to the height of peat deposition, which will permit the inhibition of the ecological succession of higher vegetation. The stability of the hydrological system of such a habitat will also allow for the preservation of important cause-and-effect relations between hydrological, geochemical conditions, and vegetation, 
which will favour the perspective of the biocoenotic stability of the ecosystem [65], including the shrub birch population. In the case of anthropogenically transformed habitats, occurring outside the system of protected areas, the best way to protect the population of $B$. humilis can be the maintenance of moderate economic use, preventing the succession of thicket-forest vegetation, e.g., through extensive cattle grazing, or controlled thinning of thickets [66]. In the case of the progressing ecological succession of habitats, in connection with the adjustment of shrub birch to the periodical destruction of its shoots (e.g., through the grazing of ruminants), moderate mowing is also admissible every several years [67]. A specific method of the active protection of many endangered plant species is reintroduction. A very important issue concerning this method is the estimation of genetic diversity in the species populations subject to restitution [68], for the purpose of determining which populations constitute the majority of its genetic resources, because they are the highest priority in the scope of protection [16].

In the case of B. humilis in the peatlands of the studied region, the perspective of potential reintroduction should be therefore related to the reconstruction of anthropogenically degraded natural habitats of the species, which must be accompanied by the regulation of water relations and an attempt to reconstruct the former biocoenotic composition. The introduction of shrub birch in such a developing biocoenosis must be based on the ex situ cultivation of seedlings originating from shoots sampled from genetically selected (with no impact of hybridisation with closely related taxa) surviving individuals of the species in a given habitat, and the distribution of seedlings in the habitat should imitate their natural distribution (irregular clusters). The experiment of the reintroduction of shrub birch conducted by the Society Chrońmy Mokradła (Centre for the Protection of Wetlands) in the Całowanie Wetland in the Mazowiecki Landscape Park since 2002 confirms the effectiveness of the method, the survival rate of the reintroduced individuals after six years reached $82.5 \%$ [19].

The permanence of measures related to the restitution of shrub birch, however, depends on the preservation of habitat conditions that are approximate to natural, including the proper level and appropriate physical-chemical specification of peatland waters.

\section{Conclusions}

(1). The specificity of the occurrence of shrub birch can indicate the character of the habitat conditions of the peatland ecosystems with a moderate climate in Central-Eastern Poland only to a low degree.

(2). Betula humilis, a late-glacial boreal relic, on the natural sites of peatlands in Central-Eastern Poland is characterised by a broad spectrum of ecological tolerance with reference to the majority of the analysed physical-chemical habitat parameters of water.

(3). A condition favouring the proper functioning of individuals of the studied species in the peatlands of the region, therefore contributing to its more abundant occurrence, is TP values lower than other obtained values, in the following range: $0.08-0.32 ; \mathrm{P}^{-\mathrm{PO}_{4}}: 0.1$; TN: $2.2-21.2$; $\mathrm{N}-\mathrm{NH}_{4}$ : 0.1-0.46; DOC: $24.6-55.9$ (in $\mathrm{mg} \cdot \mathrm{dm}^{-3}$ ), as well as higher $\mathrm{pH}$ values in the following range: 5.34-5.95; Ca: 5.67-28.1; Mg: 0.56-2.41 (in $\left.\mathrm{mg} \cdot \mathrm{dm}^{-3}\right)$ and EC: 72.1-142.3 $\left(\mu \mathrm{S} \cdot \mathrm{cm}^{-1}\right)$.

(4). The relatively broad ecological valency of the species translates into a relatively high number of confirmed sites of its occurrence in peatlands in Central-Eastern Poland, however this is subject to systematic limiting.

(5). The primary threats to the occurrence of shrub birch are related to the disturbance of the hydrological systems of the habitat and the progressing ecological succession of trees.

(6). The character of the active protection of shrub birch should depend on the degree of anthropogenic transformation of the environment, and must cover the stabilisation of the hydrological system of the habitat, restitution of the biocoenotic systems, and if necessary, extensive economy inhibiting the succession of thicket-forest vegetation, and methods for the reintroduction of the species. 
Author Contributions: A. Serafin conceived and designed the experiments; all authors performed the experiments with A. Serafin's supervision; all authors analyzed the data; U. Bronowicka-Mielniczuk elaborated the statistical analysis, A. Serafin wrote the paper with U. Bronowicka-Mielniczuk (statistics part), all authors corrected the description text.

Funding: This research received no external funding.

Conflicts of Interest: The authors declare no conflict of interest.

\section{References}

1. Wojciechowski, I. Funkcjonowanie Ekosystemów Torfowiskowych; Akademia Rolnicza w Lublinie-Katedra Ekologii Ogólnej: Lublin, Poland, 1997.

2. Kaszewski, B.M. Warunki klimatyczne Poleskiego Parku Narodowego. In Poleski Park Narodowy Monografia Przyrodnicza; Radwan, S., Ed.; Morpol: Lublin, Poland, 2002; pp. 19-28.

3. Fijałkowski, D. Zespoły Roślinne Lubelszczyzny; UMCS: Lublin, Poland, 1991.

4. Kruszelnicki, J.; Gostyńska-Jakuszewska, M.; Rutkowski, L. Salix lapponum L. (wierzba lapońska). In Polska Czerwona Księga Roślin. Paprotniki i Rośliny Kwiatowe; Kaźmierczakowa, R., Zarzycki, K., Eds.; Instytut Botaniki PAN: Kraków, Poland, 2001; pp. 71-73.

5. Churski, M.; Danielewicz, W. Salix myrtilloides in the north central Poland. Distribution, threats and conservation. Dendrobiology 2008, 60, 3-9.

6. Pogorzelec, M. Influence of chosen environmental abiotic factors on Salix lapponum L. populations in Polesie Lubelskie Region. Pol. J. Environ. Stud. 2008, 17, 581-586.

7. Pogorzelec, M. Downy willow (Salix lapponum L.) as a component of different phytocoenoses in Polesie National Park. Acta Agrobot. 2009, 62, 107-116. [CrossRef]

8. Serafin, A.; Pogorzelec, M.; Banach, B.; Mielniczuk, J. Habitat conditions of the endangered species Salix myrtilloides in Eastern Poland. Dendrobiology 2015, 73, 55-64. [CrossRef]

9. Serafin, A.; Pogorzelec, M.; Banach, B.; Szczurowska, A.; Mielniczuk, J. Physico-chemical groundwater conditions at Salix lapponum stands in Eastern Poland. Dendrobiology 2015, 73, 65-74. [CrossRef]

10. Kłosowski, G.; Kłosowski, S. Flora Polski. Rośliny Wodne i Bagienne; Multico: Warszawa, Poland, 2001.

11. Ilnicki, P. Torfowiska i Torf; Wyd. Akademii Rolniczej im. Augusta Cieszkowskiego: Poznań, Poland, 2002.

12. Tobolski, K. Torfowiska na Przykładzie Ziemi Świeckiej; Wyd. Towarzystwo Przyjaciół Dolnej Wisły: Torun, Poland, 2003.

13. Geertsema, W.; Opdam, P.; Kropff, M.J. Plant strategies and agricultural landscapes: Survival in spatially and temporally fragmented habitat. Landsc. Ecol. 2002, 17, 263-279. [CrossRef]

14. Soomers, H.; Karssenberg, D.; Verhoeven, J.T.A.; Verweij, P.A.; Wassen, M.J. The effect of habitat fragmentation and abiotic factors on fen plant occurrence. Biodivers. Conserv. 2013, 22, 405-424. [CrossRef]

15. Staszkiewicz, J.; Białobrzeska, M.; Truchanowicz, J.; Wójcicki, J.J. Variability of Betula humilis (Betulaceae) in Poland. 2. Variability of the generative organs. Fragm. Flor. Geobot. 1991, 36, 375-401.

16. Jadwiszczak, K.A.; Banaszek, A.; Jabłońska, E.; Sozinov, O.V. Chloroplast DNA variation of Betula Humilis Schrk. in Poland and Belarus. Tree Genet. Genomes 2012, 8, 1017-1030. [CrossRef]

17. Kaźmierczakowa, R.; Zarzycki, K.; Mirek, Z.; Adamowski, W.; Babczyńska-Sendek, B. Polska Czerwona Księga Roślin. Paprotniki i Rośliny Kwiatowe; Instytut Ochrony Przyrody. Polska Akademia Nauk: Kraków, Poland, 2014; ISBN 978-83-61191-72-8.

18. Hultén, E.; Fries, M. Atlas of North European Vascular Plants; Koeltz Scientific Books: Königstein, Germany, 1986.

19. Jabłońska, E. Brzoza Niska Betula Humilis Schrank w Polsce-Status Fitocenotyczny, Warunki Siedliskowe, Zagrożenia i Ochrona. Ph.D. Thesis, Uniwersytet Warszawski, Warszawa, Poland, 2009. Available online: https: / / www.researchgate.net/publication/270283403 (accessed on 4 August 2018).

20. Jabłońska, E. Vegetation with Betula humilis in Central Europe. Phytocoenologia 2012, 42, 259-277. [CrossRef]

21. Zajac, A.; Zając, M. Atlas Rozmieszczenia Roślin Naczyniowych w Polsce; Pracownia Chorologii Komputerowej Instytutu Botaniki UJ: Kraków, Poland, 2001.

22. Zarzycki, K.; Trzcińska-Tacik, H.; Różański, W.; Szalag, Z.; Wołek, J.; Korzeniak, U. Ecological Indicator Values of Vascular Plants of Vascular Plants of Poland; W. Szafer Institute of Botany, PAN: Kraków, Poland, 2002. 
23. Rozporządzenie Ministra Leśnictwa i Przemysłu Drzewnego z Dnia 30 Kwietnia 1983 r. w Sprawie Wprowadzenia Gatunkowej Ochrony Roślin. Available online: http://prawo.sejm.gov.pl/isap.nsf/ DocDetails.xsp?id=WDU19830270134 (accessed on 4 August 2018).

24. Walas, J. Atlas Roślin Chronionych; Liga Ochrony Przyrody: Warszawa, Poland, 1973.

25. Kucharczyk, M.; Szukałowicz, I. Rzadkie i zagrożone gatunki roślin Polesia Zachodniego. Kosmos 2003, 52, 321-330.

26. Zarzycki, K.; Szelag, Z. Red list of the vascular plants in Poland. In Red List of Plants and Fungi in Poland; Mirek, Z., Zarzycki, K., Wojewoda, W., Szelag, Z., Eds.; W. Szafer Institute of Botany, Polish Academy of Sciences: Kraków, Poland, 2006; pp. 11-20.

27. Harasimiuk, M.; Michalczyk, Z.; Turczyński, M. Jeziora Łęczyńsko—Włodawskie; Biblioteka Monitoringu Środowiska: Lublin, Poland, 1998.

28. Piernik, A. Metody Numeryczne w Ekologii; Wydawnictwo Naukowe Uniwersytetu Mikołaja Kopernika: Toruń, Poland, 2008.

29. Chmiel, J. Flora Roślin Naczyniowych Wschodniej Części Pojezierza Gnieźnieńskiego i Jej Antropogeniczne Przeobrażenia w Wieku XIX i XX. Cz. 1; Sorus: Poznań, Poland, 1993.

30. Chmiel, J. Flora Roślin Naczyniowych Wschodniej Części Pojezierza Gnieźnieńskiego i Jej Antropogeniczne Przeobrażenia w Wieku XIX i XX. Cz. 2, Atlas Rozmieszczenia Roślin; Sorus: Poznań, Poland, 1993.

31. R Core Team. R: A Language and Environment for Statistical Computing; R Foundation for Statistical Computing: Vienna, Austria, 2017; Available online: https://www.R-project.org/ (accessed on 4 August 2018).

32. Oksanen, J.; Blanchet, F.G.; Friendly, M.; Kindt, R.; Legendre, P.; Mcglinn, D.; Minchin, P.R.; O’Hara, R.B.; Simpson, G.L.; Solymos, P.; et al. Vegan: Community Ecology Package. R Package Version 2.5-2. 2018. Available online: http:/ /CRAN.R-project.org/package=vegan (accessed on 4 August 2018).

33. Matuszkiewicz, W. Przewodnik Do Oznaczania Zbiorowisk Roślinnych Polski; Wydawn. Naukowe PWN: Warszawa, Poland, 2001.

34. Fijałkowski, D. Vascular Flora of Lublin Region. I; Lubelskie Towarzystwo Naukowe: Lublin, Poland, 1994.

35. Blanchet, F.G.; Legendre, P.; Borcard, D. Forward selection of explanatory variables. Ecology 2008, 89, 2623-2632. [CrossRef] [PubMed]

36. Borcard, D.; Gillet, F.; Legendre, P. Numerical Ecology with R; Springer: New York, NY, USA, 2011; ISBN 978-1-4419-7976-6.

37. Legendre, P.; Legendre, L. Numerical Ecology, 2nd ed.; Elsevier: Amsterdam, The Netherlands, 1998; ISBN 0-444-89250-8.

38. Juśkiewicz-Swaczyna, B.; Choszcz, D. Effect of habitat quality on the structure of populations of Pulsatilla patens (L.) Mill. (Ranunculaceae)—Rare and endangered species of European flora. Pol. J. Ecol. 2012, 60, 567-576.

39. Skrajna, T.; Kubicka, H.; Rzymowska, Z. Illecebrum verticillatum L.-Endangered species in agrocenoses of eastern Poland: Assessment of ecological and genetic indicators for protection goals. Pol. J. Ecol. 2012, 60, 577-589.

40. Kostrakiewicz-Gieralt, K. The effect of vegetation character on abundance and structure of subpopulations of rare herb species Gentiana pneumonanthe L. Pol. J. Ecol. 2014, 61, 35-46.

41. Tilaki, G.A.D.; Kamarei, R.; Vafakhah, M. Determining the relation between soil properties and spatial variability of Nitraria schoberi Linn. Using geostatistical analysis: A case study in Meighan Playa in Iran. Pol. J. Ecol. 2013, 61, 93-104.

42. Matthies, D.; Bräuer, I.; Maibom, W.; Tscharntke, T. Population size and the risk of local extinction: Empirical evidence from rare plants. Oikos 2004, 105, 481-488. [CrossRef]

43. Lyons, K.G.; Brigham, C.A.; Traut, B.H.; Schwartz, M.W. Rare species and ecosystem functioning. Conserv. Biol. 2005, 19, 1019-1024. [CrossRef]

44. Wilgat, T. Jeziora Łęczyńsko-Włodawskie. Ann. Univ. Mariae Curie-Skłodowska Sect. B Biol. 1954, 8, 37-121.

45. Wilgat, T. Zagadnienia Ochrony środowiska w Lubelskim Zagłębiu Węglowym. Sylwan 1975, 12, $25-34$.

46. Wilgat, T. Wstęp, Czynniki terenowe kształtujące stosunki wodne, morfometria jezior, zakończenie. In Jeziora Łęczyńsko-Włodawskie; Studia Ośrodka Dokumentacji Fizjograficznej: Kraków, Poland, 1991; Volume 19.

47. Guz, T. Ekologiczna rola mokradeł w środowisku przyrodniczym Lubelszczyzny. Ekoinżynieria 1996, 1, $21-25$. 
48. Fijałkowski, D.; Urban, D. Szata roślinna obiektu wodno-torfowiskowego “Uściwierzek” i jej przekształcenia. Ann. Univ. Mariae Curie-Skłodowska Sect. C 1997, 52, 119-143.

49. Janiec, B. Naturalna i antropogeniczna ewolucja właściwości wód jezior w zachodniej części Pojezierza Łęczyńsko-Włodawskiego. In Przewodnik Ogólnopolskiego Zjazdu; PTG: Lublin, Poland, 1984.

50. Michalczyk, Z. Aktualny Stan Środowiska w Rejonie Kanału Wieprz-Krzna i Propozycje Ekologicznego Zagospodarowania Tego Terenu; Wydawnictwo Hydrotrust: Warszawa, Poland, 1992.

51. Michalczyk, Z. Zmiany sieci hydrograficznej w rejonie oddziaływania Kanału Wieprz-Krzna. In Środowisko Przyrodnicze w Strefie Oddziaływania Kanału Wieprz-Krzna; Radwan, S., Ed.; Wydawnictwo TWWP: Lublin, Poland, 1994; pp. 43-46.

52. Michalczyk, Z.; Zarębski, K. Wymiana wód podziemnych w południowo-zachodniej części Pojezierza Łęczyńsko-Włodawskiego w rejonie KWK “Bogdanka”. In Współczesne Problemy Hydrogeologii. T. 7 cz. 2; Wydawnictwo AGH: Kraków, Poland, 1995; pp. 119-126.

53. Jasnowski, M. Rozmiary i kierunki przekształceń szaty roślinnej torfowisk. Phytocoenosis 1972, 1, $193-209$.

54. Olaczek, R.; Kucharski, L.; Pisarek, W. Zanikanie obszarów podmokłych i jego skutki środowiskowe na przykładzie województwa piotrkowskiego (zlewni Pilicy i Warty). Stud. Ośrodka Dok. Fizjogr. 1990, 18, 141-199.

55. Herbich, J. Zróżnicowanie i problemy ochrony roślinności torfowisk Pojezierza Kaszubskiego. Acta Bot. Cassubica 2001, 1, 59-69.

56. Sołtys, M.; Różycki, A. Rzadkie i zagrożone gatunki flory naczyniowej w Poleskim Parku Narodowym. In Funkcjonowanie Ekosystemów Wodno-Błotnych w Obszarach Chronionych Polesia; Radwan, S., Ed.; UMCS: Lublin, Poland, 1996; pp. 89-95.

57. Fijałkowski, D. Zmiany szaty roślinnej na Lubelszczyźnie w ostatnim dwudzietoleciu. Ann. Univ. Mariae Curie-Skłodowska Sect. C 1988, 43, 215-238.

58. Boiński, M.; Boińska, U.; Ceynowa-Giełdon, M. Charakterystyka Fitosocjologiczna rezerwatu wodno-torfowiskowego "Mętno" na obszarze Borów Tucholskich. Acta Univ. Nicol. Copernic. Biol. 1975, 17, 89-113.

59. Fijałkowski, D. Szata roślinna Jezior Łęczyńsko-Włodawskich i przylegających do nich torfowisk. Ann. Univ. Mariae Curie-Skłodowska Sect. B 1959, 14, 131-207.

60. Larcher, W. Physiological Plant Ecology: Ecophysiology and Stress Physiology of Functional Groups; Springer: Berlin, Germany, 2003.

61. Gawlik, J.; Dębek, W. Ekosystemy torfowiskowe Polesia (Rodzaje i Przemiany Strukturalne). Acta Agrophys. 2002, 66, 121-145.

62. Schep, S.A.; Zeefat, R.; van Zuidam, J.P. The Relationship between Site Conditions, Nutrient Availability and Vegetation in Western-Siberian Mires-A Reference for Western-European Mires; Manuscript; Utrecht University: Utrecht, The Netherlands, 2003; p. 105.

63. El Kahloun, M.; Gerard, M.; Meire, P. Phosphorus and nitrogen cycling in fen vegetation along different trophic conditions in the Biebrza valley, Poland. Ecohydrol. Hydrobiol. 2005, 5, 67-78.

64. Wheeler, B.D.; Proctor, M.C.F. Ecological gradients, subdivisions and terminology of north-west European mires. J. Ecol. 2000, 88, 187-203. [CrossRef]

65. Joosten, H.; Clarke, D. Wise Use of Mires and Peatlands_Background and Principles Including a Framework for Decision-Making; International Mire Conservation Group and International Peat Society: Saarijärvi, Finland, 2002.

66. Kamiński, D.; Kamińska, A.M.; Załuski, T. Populacja brzozy niskiej Betula humilis Schrank na terenie projektowanego rezerwatu “Ostoje Koszelewskie" w Welskim Parku Krajobrazowym. Przeglad Przyr. 2000, 11, 125-131.

67. Szańkowski, M. Zbiorowiska Brzozy Niskiej (Betula Humilis Schrank) w Białowieskim Parku Narodowym i Ich Przyszłość w Środowisku Uwolnionym Spod Presji; Wydawnictwo UW: Warszawa, Poland, 1991.

68. Ellstrand, N.C.; Elam, D.R. Population genetic consequences of small population size: Implications for plant conservation. Annu. Rev. Ecol. Syst. 1993, 24, 217-242. [CrossRef]

(C) 2018 by the authors. Licensee MDPI, Basel, Switzerland. This article is an open access article distributed under the terms and conditions of the Creative Commons Attribution (CC BY) license (http://creativecommons.org/licenses/by/4.0/). 